\title{
INVESTIGATION OF THE CHEMICAL CHARACTERISTICS AND OXIDATIVE STABILITY OF SOME COMMERCIAL COLD-PRESSED OILS
}

\author{
${ }^{1}$ Hamide Filiz AYYILDIZ ${ }^{(D)}$, 2 Mustafa TOPKAFA $(\mathbb{D})$, ${ }^{3}$ yed Tufail Hussain SHERAZI ${ }^{(\mathbb{D})}$, \\ ${ }^{3}$ Sarfaraz Ahmed MAHESAR (D), ${ }^{4}$ Huseyin KARA \\ ${ }_{1}^{1}$ Department of Basic Pharmaceutical Sciences, Faculty of Pharmacy, Selcuk University, Konya, TURKEY \\ ${ }^{2}$ Vocational School of Technical Sciences, Department of Chemistry and Chemical Processing Technologies, Konya \\ Technical University, Konya, TURKEY \\ ${ }^{3}$ National Centre of Excellence in Analytical Chemistry, University of Sindh, Jamshoro, PAKISTAN \\ ${ }^{4}$ Faculty of Science, Department of Chemistry, Selcuk University, Konya, TURKEY \\ ${ }^{1}$ hfayyildiz@selcuk.edu.tr, ${ }^{2}$ mtopkafa@ktun.edu.tr, ${ }^{3}$ tufail.sherazi@yahoo.com, ${ }^{3}$ sarfaraz.mahesar@usindh.edu.pk, \\ ${ }^{4}$ hkara@selcuk.edu.tr
}

(Geliş/Received: 14.04.2021; Kabul/Accepted in Revised Form: 09.09.2021)

\begin{abstract}
In this study, the chemical composition and oxidative stability of cold-pressed flaxseed, black seed, pumpkin seed, walnut seed, and poppy seed oils were examined. The results showed that the seed oils contained appreciable amounts of unsaturated fatty acids (above $79 \%$ ). Polyunsaturated fatty acids, particularly linoleic acids were dominant, with values ranging from $53.24 \%-71.37 \%$ of the total amount of fatty acids except for pumpkin seed oil. Tocols content was found to be between $\sim 490-932 \mathrm{mg}$ $\mathrm{kg}^{-1}$, and the flaxseed oil exhibited the highest levels of total tocopherols $\left(977.47 \mathrm{mg} \mathrm{kg}^{-1}\right)$ under the experimental conditions. While, the highest PV was found in walnut seed oil $\left(2.81 \mathrm{meq} \mathrm{O}_{2} \mathrm{~kg}^{-1}\right)$, and the highest content of FFAs was reported for flaxseed oil (1.82 \%). OSI values were 4.15, 3.57, 4.31, 3.98 and $4.92 \mathrm{~h}$ for the flaxseed, black seed, pumpkin seed, walnut seed, and poppy seed oils, respectively. The obtained data suggest that the seed oils in this study may serve as special dietary sources.
\end{abstract}

Key Words: Cold pressed seed oils, Fatty acid composition, Tocol profile, Oxidative stability, Rancimat

\section{Bazı Ticari Soğuk Pres Yağların Kimyasal Özelliklerinin ve Oksidatif Kararlılığının İncelenmesi}

ÖZ: Bu çalışmada, soğuk pres keten tohumu, çörek otu, kabak çekirdeği, ceviz ve haşhaş tohumu yağlarının kimyasal bileşimi ve oksidatif stabilitesi incelenmiştir. Sonuçlar, çekirdek yağlarının kayda değer miktarlarda doymamış yağ asitlerini içerdiğini (\% 79'un üzerinde), bunlar arasında ise çoklu doymamış yağ asitlerinin, özellikle de linoleik asitlerin, kabak çekirdeği yağı hariç diğer yağlardaki toplam yağ asidi miktarının \% 53.24 ile \% 71.37'si arasındaki değerlerde baskın olduğunu göstermiştir. Yağların tokol içeriği 490-932 $\mathrm{mg} \mathrm{kg}^{-1}$ arasında bulunmuş ve deney koşullarındaki en yüksek toplam tokoferol düzeyi (977.47 $\mathrm{mg} \mathrm{kg}^{-1}$ ) keten tohumu yağında tespit edilmiştir. En yüksek PV değeri ceviz yağında rapor edilmiş $\left(2.81\right.$ meq $\left.\mathrm{O}_{2} \mathrm{~kg}^{-1}\right)$, en yüksek FFA içeriği ise keten tohumu yağında (\%1.82) bulunmuştur. OSI değerleri; keten tohumu, çörek otu, kabak çekirdeği, ceviz ve haşhaş tohumu yağları için sırasıyla 4.15, 3.57, 4.31, 3.98 ve 4.92 saat olarak tespit edilmiştir. Elde edilen veriler, bu çalışmadaki tohum yağlarının özel diyet kaynakları olarak kullanılabileceğini göstermektedir. 


\section{INTRODUCTION}

Crude edible oils contain many components like glycerides (mono, di, and tri), free fatty acids (FFAs), colour pigments, phosphatides, sterols, tocotrienols, tocopherols, hydrocarbons, some trace metals, etc. (Lacoste, 2014). Based on the nutritional point of view, most of these components are very important. But due to their sensory, odour, taste, and volatility issues, some of these constituents are supposed to be impurities found in the edible oils (Čmolík and Pokorný, 2000). A process through which these impurities are removed from crude oils is called "refinery". Oils need to be refined to obtain an odourless liquid with enhanced oxidative stability and a bland taste (Medina-Juárez and Gámez-Meza, 2011). Degumming, neutralization, bleaching, winterization, and deodorization are the key stages in the oil refining process (Pal et al., 2015). But unfortunately, each processing stage leads to a decrease in bioactive components such as sterols, phenols, tocopherols, tocotrienols, aromas, etc. The amount of each bioactive material lost during refining is determined by the input oil's composition, processing parameters, and efficiency (Naz et al., 2011).

In the last few years, oils produced by mechanical extraction (cold-pressed) without any solvents have been made available to consumers. (Cakaloglu et al., 2018; Yusuf, 2018; Ramadan, 2020). This oil is obtained from different nutty fruits or oilseeds. Consumers appreciate the unique and characteristic taste, the specific aroma, and the intensive color (Cakaloglu et al., 2018) and prefer to use it for cold dishes or salads (Vujasinovic et al., 2010). Generally, compared to refined oils, cold-pressed oils have more nutritional value. They include more natural beneficial ingredients such as tocopherols, sterols, phospholipids, and carotenoids, partially removed at the end of oil refining (Pachuau et al., 2019). Many different data confirm the chemical quality and good sensory properties of cold-pressed oils. (Celenk et al., 2018).

Due to the wide range of edible oil applications, proper knowledge about their composition and quality parameters is vital (Febrianto and Yang, 2011). The fatty acid composition (FAC) of vegetable oils differ from each other according to the length of carbon chains and the number of double bonds (Wardana et al., 2018). In the diet, vegetable oils play a crucial role and contribute to the supply of energy. Vegetable oils are the primary sources of essential fatty acids such as linoleic (C18:2) and $\alpha$-linolenic acid (C18:3), which is a pioneer and precursor omega- 6 and omega-3 family (Frančáková et al., 2015), believed to be necessary for the proper functioning of the human body, as well as development and physiological activities (Ying et al., 2018). The total amount of these fatty acids is attributed to many diseases such as high blood cholesterol, obesity, coronary heart disease, and cancer (Ferguson et al., 2016; Froyen and Burns-Whitmore, 2020).

In vegetable oils, antioxidants (tocopherols and tocotrienols) are present naturally. Their primary function is to keep the stability of oil by preventing free radicals (Yamauchi, 1997). Naturally occurring compounds with vitamin E activity consist of $\alpha-, \beta-, \gamma-, \delta$ - tocopherols and tocotrienols. All members of Vitamin E have a positive rolein the health of consumers (Žilić et al., 2010; Prescha et al., 2014). Oxidative stability is directly linked to the duration of the oil's shelf life and is influenced by several reasons (Grajzer et al., 2020). FAC, antioxidant content, FFA, peroxides, processing conditions, heat, light, and oxygen concentration are some of these factors (Choe and Min, 2006; Budilarto and Kamal-Eldin, 2015). Chemical analyses generally evaluate the oxidative stabilities of oils include the determination of oxidation stability index (OSI), iodine value (IV), peroxide value (PV) and FFA. The rancimat system measures a heated sample's conductivity at elevated temperature, by which streams of air are transferred, and it can be used to assess the antioxidant effects of tocols (Ayyildiz et al., 2015).

FFA is the most critical quality indicator and measured as \% FFA in the oil (Ayyildiz et al., 2011). PV is the number of mill equivalents of oxygen which represents the concentration of peroxide present in the $1 \mathrm{~kg}$ of oil and shows the level of oxidation. The IV is the amount of iodine in grams retained by $100 \mathrm{~g}$ of oil, and it is a parameter that signifies the oil's degree of unsaturation of the oil. A lower IV indicates the presence of a less quantity of double bonds and more saturated FAs (Kyriakidis and Katsiloulis, 2000).

The main objective of the present study were $(i)$ to evaluate the FAC of the mechanically cold-pressed flaxseed, black seed, pumpkin seed, walnut seed, and poppy seed oils produced in Turkey and (ii) to determine and compare the OSI of CPSOs. 


\section{MATERIALS AND METHODS}

\subsection{Chemicals, solvents, and samples}

All the solvents and chemicals used in the present study were of the analytical and chromatographic grade obtained from BDH (Poole, UK) and Merck (Darmstadt, Germany). The standards of the tocopherols, tocotrienols and fatty acid methyl esters (FAMEs), which was the mixture of 37 components were purchased from Supelco (Bellefonte, PA, USA).

Cold-pressed seed oils (flaxseed, black seed, pumpkin seed, walnut seed, and poppy seed) were purchased from local markets in Konya (Turkey). The oil samples were kept in brown glass bottles and stored at $4^{\circ} \mathrm{C}$ to protect against any oxidation until analysis.

\subsection{Preparation of fatty acid methyl esters (FAME)}

For the preparation of FAME of the cold press oils, the method previously recommended by EU regulation 2568/91was used (Commission, 1991). For this, approximately weighed $100 \mathrm{mg}$ of each coldpressed oil sample into a screw-capped glass tube, and $10.0 \mathrm{~mL}$ hexane was added. After the addition of $100 \mu \mathrm{L}$ of $2 \mathrm{~N}$ ethanolic $\mathrm{KOH}$ solution, the mixture was vigorously shaken for $30 \mathrm{~s}$. Then it was centrifuged at $2500 \mathrm{rpm}$ for $5 \mathrm{~min}$. The supernatant obtained from the process was transferred to vials through filtration using $0.45 \mu \mathrm{m}$ pore size filter paper and stored at $0{ }^{\circ} \mathrm{C}$ in the refrigerator until analysis.

\subsubsection{Analysis of FAME by GC-FID}

For the study of FAMEs, an Agilent $6890 \mathrm{~N}$ gas chromatography system attached with a flame ionization detector (FID) (Agilent Technologies Inc., Wilmington, DE, USA) was used. The samples $(1 \mu \mathrm{L})$ were injected through an auto-sampler (an Agilent 7683 series) in a split-split injection mode at a ratio of 100: 1. Helium and hydrogen gases were used as and makeup and a mobile phase, respectively. For the separation of FAMEs, HP-88 cyanopropyl capillary column (highly polar) with $100 \mathrm{~m} \times 0.25 \mathrm{~mm} \times 0.2 \mu \mathrm{m}$ in size was used. The temperature of the injection and detector was kept at $250^{\circ} \mathrm{C}$. The oven temperature started from $45^{\circ} \mathrm{C}$ with 4 min stay time, then it was increased to $175^{\circ} \mathrm{C}$ at the rate of $13^{\circ} \mathrm{C} \mathrm{min}^{-1}$, and 27 min was kept the stay time. Then the temperature was raised to $215^{\circ} \mathrm{C}$ at the rate of $4{ }^{\circ} \mathrm{C} \mathrm{min}{ }^{-1}$. Hold time was $35 \mathrm{~min}$ at the final temperature. The $\mathrm{H}_{2}$ and an air flow rate of 30 and $300 \mathrm{~mL} \mathrm{~min}^{-1}$ were used as detector gases, respectively. 1200 Series-B.03.02 Agilent software program was used to record the chromatograms of the FAMEs. Individual identification of FAs was performed by comparing the FAME mix's retention times on the HP-88 column under the same conditions and reported as the FA percentage.

\subsection{Analysis of tocopherols \& tocotrienols by NP-HPLC}

Analysis of tocopherols \& tocotrienols was carried out by normal phase HPLC system comprising the following components; a G1311A model quaternary pump, a G1379A model degasser, a 7725i model Rheodyne manual injector system ( $2 \mu \mathrm{L}$ loop), a G1321B model fluorescence detector (FLD) and a G1316A model thermostatted column compartment. B.03.02-2008 Chemstation data processor (Wilmington, DE, USA) was used to record the data.

For the determination of tocopherol and tocotrienols, $1 \mathrm{~g}$ oil samples were dissolved in $10 \mathrm{~mL}$ hexane and $2 \mu \mathrm{L}$ was injected directly into HPLC through a guard column $(7.5 \mathrm{~cm} \times 0.4 \mathrm{~cm} \times 5 \mu \mathrm{m}$ in size $)$ coupled to a LiChrospher 100 Diol column, $25 \mathrm{~cm} \times 0.4 \mathrm{~cm} \times 5 \mu \mathrm{m}$ in size (Teknokroma, Barcelona, Spain) as reported in the literature (Kramer et al., 1997). Analysis was carried by an isocratic elution mode at $25^{\circ} \mathrm{C}$. A mixture of hexane and 2-propanol (99.4: 0.6, v/v) was used as the mobile phase. The flow rate was kept at $1.5 \mathrm{~mL}$ $\mathrm{min}^{-1}$. The peaks obtained were detected using an FLD detector kept constant at $25^{\circ} \mathrm{C}$, with excitation and emission wavelengths set to $295 \mathrm{~nm}$ and $320 \mathrm{~nm}$. 
The tocopherol species' identity was determined by comparing the retention times of the peaks obtained with known tocopherol standards. All standard solutions were freshly prepared and stored in the dark at $0{ }^{\circ} \mathrm{C}$ until analysis. In the quantitative determination of tocol homologs, calibration graphs created by taking into account the peak areas of the mixed tocopherol and tocotrienol standards were used.

\subsection{Determination of oxidative stability index (OSI) by Rancimat}

For the determination of OSI, 743 Rancimat systems (Methrom AG, Herisau, Switzerland) according to the AOCS Cd 12b-92 method (AOCS, 1998c) was used. Briefly, $3.0 \mathrm{~g}$ of the oil sample was weighed in the reaction vessel. Then placed in the heating block at $120{ }^{\circ} \mathrm{C}$ temperature and exposed with $20 \mathrm{~L} \mathrm{~h}^{-1}$ airflow. During the process, produced volatile compounds were collected in a bottle containing $50 \mathrm{~mL}$ of distilled water. Then conductivity of the solution was recorded. The induction period was found out as a variation point in the graph drawn by taking into account the conductivity value of water $\left(\mu \mathrm{cm}^{-1}\right)$ varying against time (h). All analyses were carried out in triplicate, and the results are reported as the average of the obtained values.

\subsection{Determination of free fatty acid (FFA) analyses}

The FFA values of oil samples were evaluated as per AOCS Ca 5a-40 method (AOCS, 1998b). Sodium hydroxide solution $(0.1000 \mathrm{~N})$ was utilized as a titrant, while potassium acid phthalate was used in setting the titrant solution as the primary standard substance and phenolphthalein solution (1\% PHP) as an indicator in titration. Triplicate analyses were performed for each oil sample.

\subsection{Determination of peroxide value (PV)}

The standard AOCS Cd 8b-90 method (AOCS, 1996) was used for the determination of PV of the oil samples. For this purpose, a $10 \mathrm{~g}$ oil sample was dissolved in $25 \mathrm{~mL}$ of a chloroform / acetic acid mixture $(2: 3, \mathrm{v} / \mathrm{v})$. After adding $1 \mathrm{~mL}$ of potassium iodide solution, it was left in the dark for exactly $3 \mathrm{~min}$ for the reaction to occur. Then, $20 \mathrm{~mL}$ of distilled water and $1 \mathrm{~mL}$ of indicator (1\% starch) were added to the solution, and the liberated iodine was titrated with $0.002 \mathrm{~N}$ sodium thiosulfate solution. Results achieved through triplicate determinations are given as meq $\mathrm{O}_{2} \mathrm{~kg}^{-1}$ oil.

\subsection{Determination of iodine value (IV)}

The standard AOCS Cd 1-25 method (AOCS, 1998a) was used to determine the IV of the oil samples. As per procedure, a $10 \mathrm{~g}$ of oil sample was added to $10 \mathrm{~mL}$ of carbon tetrachloride containing $1 \mathrm{~mL}$ of Wijs solution (ICl dissolved in glacial acetic acid) and left in the dark for 1 hour for the reaction to occur. After that, saturated potassium iodide $(15 \mathrm{~mL})$ and water $(100 \mathrm{~mL})$ were added. The iodine released was titrated against sodium thiosulfate solution $(0.002 \mathrm{~N})$. Obtained results at the end of triplicate determinations are expressed as the gram iodine number per 100 grams of oil (g I2 $100 \mathrm{~g}-1$ oil).

\subsection{Analysis of data}

The data obtained from the analyses performed in triplicate $(n=3)$ are given as mean \pm SD (standard deviation). For the determination of the differences between the averages, least significant difference tests and analysis of variance were applied. Statistical significance value was taken into account as $\mathrm{P}<0.05$.

\section{RESULTS AND DISCUSSION}

In this paper, cold-pressed flaxseed, black seed, pumpkin seed, walnut seed, and poppy seed oils were examined for their FFA, PV, IV, FAC, tocols profile, and OSI. 


\subsection{Fatty acid composition (FAC)}

The FAC identifies the stability, nutritional values, and physical properties of edible oils. The FAs in naturally sourced glycerol molecules are composed of different percentages of saturated (SFA), monounsaturated (MUFA), and polyunsaturated (PUFA) fatty acids, and the distribution of these fatty acids differ according to the origin of the oilseeds and fruits and climate cultivation (Kris-Etherton et al., 2000). The vegetable oils have diverse sensitivities to oxidative degradation because of the variations in the degree of unsaturation of their FAs. The previous studies reported that the saturated oils are oxidized less quickly than unsaturated oils; the relative auto-oxidation rate of PUFAs, oleic (18:1 $\Delta$ 9c), linoleic (18:2 $\Delta 9 \mathrm{c}, 12 \mathrm{c})$, and linolenic acids $(18: 3 \Delta 9 \mathrm{c}, 12 \mathrm{c}, 15 \mathrm{c})$, are 1:40 to $50: 100$ on the basis of oxygen uptake, and 1:12:25 on the basis of peroxide formation. Thus, the distribution of FAs in vegetable oils is very important for consumers in terms of diet and health (Orsavova et al., 2015; Özbek et al., 2020). Health professionals recommend diets with low energy, low cholesterol, low SFA, and a good n6/n3 ratio to decrease heart disease and others (Briggs et al., 2017).

The FAC of examined cold-pressed seed oils is summarized in Table 1. Also, the GC-FID chromatogram of FAME isomers for cold-pressed flaxseed oil is shown in Fig. 1.

Table 1. Fatty acid composition (FAC) of tested cold-pressed seed oils (\%)

\begin{tabular}{|c|c|c|c|c|c|}
\hline Fatty Acids & Flaxseed & Black seed & $\begin{array}{c}\text { Pumpkin } \\
\text { seed }\end{array}$ & $\begin{array}{c}\text { Walnut } \\
\text { seed }\end{array}$ & $\begin{array}{c}\text { Poppy } \\
\text { seed }\end{array}$ \\
\hline 14:0 & nd & $0.31 \pm 0.04$ & $0.09 \pm 0.01$ & $0.03 \pm 0.01$ & $0.05 \pm 0.01$ \\
\hline $16: 0$ & $5.40 \pm 0.62$ & $12.24 \pm 1.02$ & $11.98 \pm 0.65$ & $7.04 \pm 0.56$ & $9.16 \pm 0.56$ \\
\hline $16: 1$ trans & nd & nd & $0.01 \pm 0.01$ & $0.04 \pm 0.01$ & nd \\
\hline $16: 1$ & $0.07 \pm 0.02$ & $0.22 \pm 0.06$ & $0.15 \pm 0.02$ & $0.12 \pm 0.03$ & $0.13 \pm 0.01$ \\
\hline 17:0 & $0.04 \pm 0.01$ & $0.12 \pm 0.06$ & $0.07 \pm 0.02$ & $0.07 \pm 0.03$ & $0.05 \pm 0.01$ \\
\hline $17: 1$ & nd & nd & $0.04 \pm 0.01$ & $0.04 \pm 0.02$ & $0.04 \pm 0.02$ \\
\hline 18:0 & $3.74 \pm 0.05$ & $3.53 \pm 0.07$ & $5.27 \pm 0.12$ & $2.77 \pm 0.09$ & $2.40 \pm 0.05$ \\
\hline 18:1 trans & nd & nd & nd & $0.02 \pm 0.01$ & nd \\
\hline 18:1 ( $\omega 9)$ & $23.15 \pm 0.42$ & $24.90 \pm 0.36$ & $27.58 \pm 0.48$ & $17.64 \pm 0.34$ & $15.50 \pm$ \\
\hline $18: 2$ trans & nd & nd & $0.03 \pm 0.01$ & $0.03 \pm 0.01$ & $0.04 \pm 0.02$ \\
\hline $18: 2(\omega 6)$ & $16.75 \pm 0.46$ & $54.80 \pm 0.62$ & $53.24 \pm 0.35$ & $59.69 \pm 0.78$ & $71.37 \pm$ \\
\hline 18:3 trans & nd & nd & $0.37 \pm 0.04$ & $0.08 \pm 0.03$ & $0.14 \pm 0.07$ \\
\hline $20: 0$ & $0.36 \pm 0.10$ & $0.24 \pm 0.05$ & nd & $0.07 \pm 0.03$ & nd \\
\hline $18: 3(\omega 3)$ & $50.14 \pm 0.71$ & $0.29 \pm 0.07$ & $0.39 \pm 0.08$ & $12.22 \pm 0.53$ & $0.56 \pm 0.10$ \\
\hline $20: 1$ & nd & $0.25 \pm 0.08$ & $0.15 \pm 0.05$ & nd & $0.12 \pm 0.05$ \\
\hline $20: 2$ & nd & nd & $0.02 \pm 0.01$ & $0.03 \pm 0.01$ & $0.03 \pm 0.01$ \\
\hline 21:0 & nd & nd & nd & $0.01 \pm$ & nd \\
\hline 22:0 & $0.24 \pm 0.09$ & $0.41 \pm 0.07$ & $0.11 \pm 0.03$ & $0.03 \pm 0.01$ & $0.09 \pm 0.02$ \\
\hline $22: 1$ & nd & nd & nd & $0.01 \quad 0.01$ & nd \\
\hline 23:0 & nd & nd & $0.05 \pm 0.01$ & $0.01 \pm 0.01$ & nd \\
\hline $24: 0$ & $0.13 \pm 0.03$ & $0.15 \pm 0.04$ & $0.09 \pm 0.02$ & $0.01 \pm 0.01$ & nd \\
\hline$\sum S F A s$ & $9.14 \pm 0.22$ & $15.77 \pm 0.23$ & $17.7 \pm 0.51$ & $10.01 \pm 0.20$ & $11.72 \pm$ \\
\hline$\sum M U F A s$ & $23.14 \pm 0.34$ & $24.90 \pm 0.30$ & $27.92 \pm 0.36$ & $17.81 \pm 0.24$ & $15.75 \pm$ \\
\hline$\sum$ PUFAs & $66.89 \pm 0.51$ & $54.80 \pm 0.72$ & $54.02 \pm 0.49$ & $72.02 \pm 0.73$ & $72.01 \pm$ \\
\hline Trans fatty acids & nd & nd & $0.04 \pm 0.01$ & $0.09 \pm 0.02$ & $0.04 \pm 0.02$ \\
\hline
\end{tabular}

Data are reported as mean \pm SD of three replicate analyses $(\mathrm{n}=3)$

nd; not detected, PUFA; polyunsaturated fatty acids, MUFA; mono unsaturated fatty acids, SFA; Saturated fatty acids. 


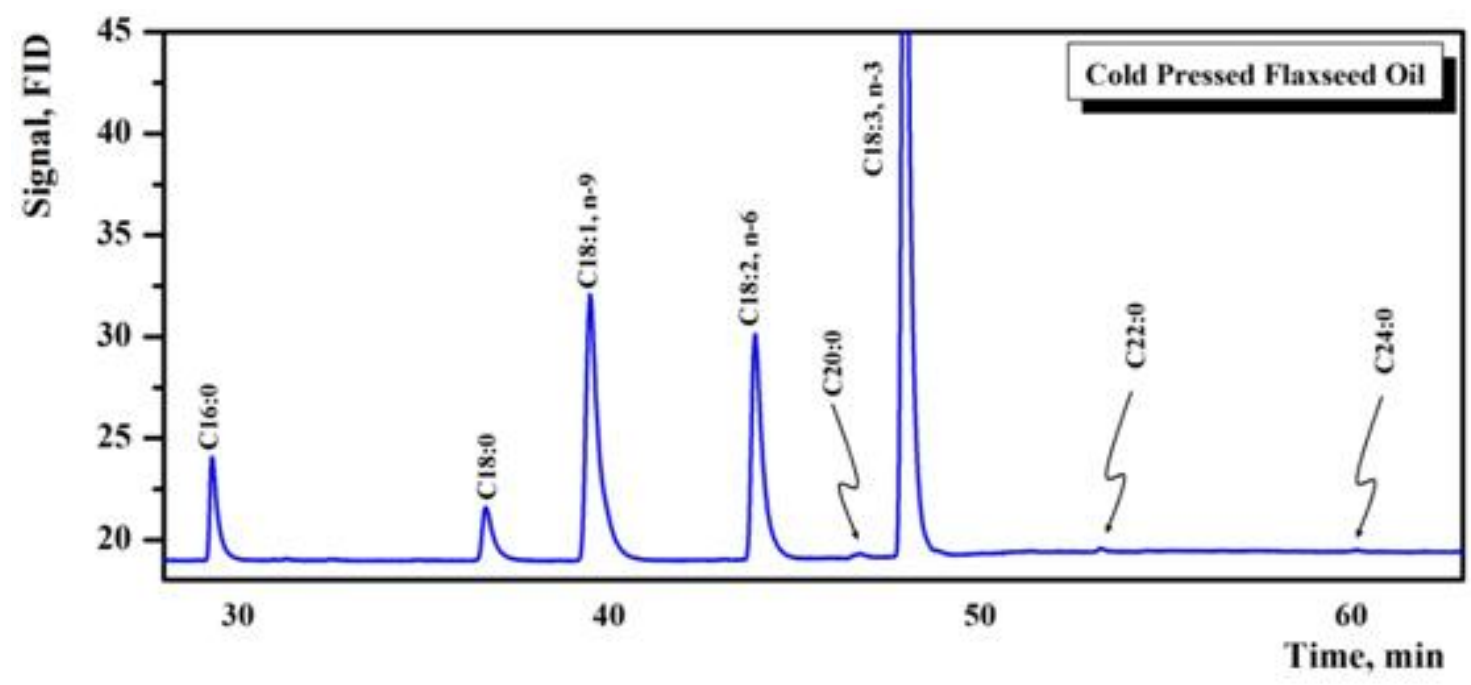

Figure.1. The GC-FID chromatogram for FAME isomers of tested cold-pressed flaxseed oil

Table 1 showed that cold-pressed flaxseed, black seed, pumpkin seed, walnut seed, and poppy seed oils are excellent natural sources of essential PUFAs which may act as mediators for the immune and nervous systems by regulating and altering the gene expression, membrane structure, and influencing prostaglandin (Yehuda et al., 2001). Two of the PUFAs types, n-6 and n-3, have more importance than the others. Rather than taking these PUFAs individually, their ratio is important. Namely, the n-6 / n-3 ratio in the diet regulates gene expression, affects neurological controls, and regulates immune function. (Vidrih et al., 2010). The high n-6 / n-3 ratio in dietary fat is believed perilous (Griffin, 2008; Husted and Bouzinova, 2016). The majority of today's diet is made up of n-6 fatty acids, where n-3 fatty acids are almost absent or very little. The studies about the dietary intake show that the n- 6 / n-3 ratio in today's diets is around 14:1 to 20:1. Most studies show that the n- 6 / n-3 ratio must be among 4: 1 and 10: 1 to reach good health benefits (Wijendran and Hayes, 2004). Cold-pressed edible oils had about $54.02 \%$ to $72.02 \%$ total polyunsaturated fatty acids ( $\sum$ PUFAs). Besides, cold-pressed walnut seed oil had the maximum level of PUFAs (72.02\%) and an excellent n-6/n-3 ratio (4.9) because of a high percentage of linolenic acid (18:3 n3). The cold-pressed flaxseed oil with 66.89 \% PUFAs content followed the cold-pressed walnut seed oil. The FAC of these oils was in the range of that previously reported in cold-pressed walnut seed and flaxseed oil (Khattab and Zeitoun, 2013; Grajzer et al., 2020).

As shown in Table 1., the cold-pressed oils are also rich in MUFAs and contain low content of total SFAs. A diet rich in MUFA is vital for lowering blood cholesterol levels and modulating immune function (Yaqoob, 1998). Oleic acid (18:1 n9) was the major source of MUFAs for both cold-pressed. SFA contents in analyzed cold-pressed seed oils showed slight differences between $9.14-17.70 \%$ of total FAs. The major SFA was a palmitic acid (16:0), followed by stearic acid (18:0). Other minor SFAs were also detected, such as 14:0, 20:0, 22:0, and 24:0. Amongst the tested oils, pumpkin cold-pressed seed oil showed maximum SFAs content $(17.70 \%)$. These results are comparable to those reported previously, with only a few variations (Vujasinovic et al., 2012; Grajzer et al., 2020).

The total TFAs isomers comprised of the C16:1, C18:1, C18:2, and C18:3 FAs. Even though TFAs are found in cold press vegetable oils, their quantities were extremely low (less than $0.1 \%$ of the total FAs). Trans C18:3 acid was predominant in cold-pressed oils, whereas no TFAs were detected in flaxseed and black seed oils.

\subsection{Tocopherols (-T) and tocotrienols (-TT) profile}

The tocols known as naturally occurring compounds in oils indicate the oil quality, stability, origin, or nutritional values. They may also provide additional consumer health advantages in disease prevention due to their anti-oxidative and vitamin E activity (Delgado et al., 2020). Moreover, these compounds are 
used as lipid stabilizers in several food industries. In theory, $\alpha$-tocopherol has the most prominent biological activity among all homologs. However, the other tocopherol forms also have high vitamin $\mathrm{E}$ activity and antioxidants properties (Traber and Atkinson, 2007; Uluata and Özdemir, 2012).

During the quantitative determination of tocopherol and tocotrienols, which were performed with very little modification of the procedures in the literature, different calibration graphs were created for each cold-pressed oil, taking into account the levels of tocols. Parameter values used for the validation of the method applied; The calibration range $\left(\mathrm{mg} \mathrm{kg}^{-1}\right)$, regression coefficient (R2), LOD ( $\left.\mathrm{mg} \mathrm{kg}^{-1}\right)$, LOQ (mg $\left.\mathrm{kg}^{-1}\right)$, precision $(\mathrm{CV} \%)$, and recovery $(\%)$ are presented in Table 2. Exceptional regression coefficient $\mathrm{R}^{2}(\geq$ $0.9935)$ was observed with excellent LOD $(\leq 0.76)$ and LOQ $(\leq 2.53)$ for both tocopherol and tocotrienols.

Table 3 shows the individual attitudes of the $\alpha-,-\beta,-\gamma$ and $-\delta$ homologues in the content of the coldpressed seed oils studied. All tocols forms were effectively separated by a diol column on the NP-HPLC system using an FLD, taking into account the separation of $\beta$-T and $\gamma$-T types, complicated to distinguish. (Fig. 2).

As can be noticed in Table 3, the content of total tocols ranges from $490.24-977.47 \mathrm{mg} \mathrm{kg}^{-1}$ oil for all tested seed oils., The flaxseed oil, among the cold-pressed seed oils was the richest in tocols content, 977.47 $\mathrm{mg} \mathrm{kg}{ }^{-1}$ oil containing $\alpha-\mathrm{T}\left(16.19 \mathrm{mg} \mathrm{kg}^{-1}\right), \beta-\mathrm{T}\left(222.88 \mathrm{mg} \mathrm{kg}^{-1}\right), \gamma-\mathrm{T}\left(721.25 \mathrm{mg} \mathrm{kg}^{-1}\right)$ and $\delta-\mathrm{T}\left(17.14 \mathrm{mg} \mathrm{kg}^{-}\right.$ $\left.{ }^{1}\right)$. In contrast, the black seed oil draws attention with tocotrienol profile as a major tocol homologs containing $\alpha$-TT (100.78 $\left.\mathrm{mg} \mathrm{kg}^{-1}\right)$, $\beta$-TT (295.84 $\left.\mathrm{mg} \mathrm{kg}^{-1}\right)$, and $\gamma$-TT (13.71 $\left.\mathrm{mg} \mathrm{kg}^{-1}\right)$. Walnut seed and pumpkin seed oils also contained an appreciably greater quantity of $\gamma$-TT as 18.71 and $17.20 \mathrm{mg} \mathrm{kg-1}$, respectively, predominant over other tocotrienol homologs. The obtained values of tocols differ from the reported values (Grajzer et al., 2020). It may be due to the difference in the variety of oilseeds, environmental conditions, and origin (Szydłowska-Czerniak et al., 2008; Neđeral et al., 2012).

Table 2. Validation parameters for identification of tocols in cold-pressed seed oils studied

\begin{tabular}{|c|c|c|c|c|c|c|c|}
\hline Parameters & $\begin{array}{c}\alpha-T \\
t_{\mathrm{R}}= \\
7.50 \pm 0.2 \\
\min \end{array}$ & $\begin{array}{c}\beta-T \\
t_{\mathrm{R}}= \\
16.46 \pm 0.2 \\
\min \end{array}$ & $\begin{array}{c}\gamma-T \\
t_{R}=17.26 \pm 0.2 \\
\min \end{array}$ & $\begin{array}{c}\delta-T \\
t_{R}= \\
27.48 \pm 0.2 \\
\min \end{array}$ & $\begin{array}{c}\alpha-T T \\
t_{\mathrm{R}}= \\
12.68 \pm 0.2 \\
\min \end{array}$ & $\begin{array}{c}\beta-T T \\
\mathrm{t}_{\mathrm{R}}=19.91 \pm 0.2 \\
\min \end{array}$ & $\begin{array}{c}\gamma-T T \\
\mathrm{t}_{\mathrm{R}}= \\
25.88 \pm 0.2 \\
\min \end{array}$ \\
\hline & \multicolumn{7}{|c|}{ Standard linearity } \\
\hline Range (mg kg-1) & $0-100$ & $0-1000$ & $0-1000$ & $0-50$ & $0-100$ & $0-500$ & $0-250$ \\
\hline $\mathbf{R}^{2}$ & 0.9985 & 0.9976 & 0.9984 & 0.9993 & 0.9959 & 0.9938 & 0.9993 \\
\hline \multirow[t]{2}{*}{ Precision $(\mathrm{CV} \%), \mathrm{n}=3$} & 2.0 & 3.4 & 2.9 & 4.5 & 2.6 & 3.1 & 1.2 \\
\hline & \multicolumn{7}{|c|}{ Accuracy } \\
\hline \multirow[t]{2}{*}{ Mean Recovery (\%) } & 98.2 & 99.6 & 97.9 & 101.0 & 99.8 & 99.9 & 101.2 \\
\hline & \multicolumn{7}{|c|}{ Sensitivity } \\
\hline LOD (mg kg-1) & 0.60 & 0.5 & 0.22 & 0.76 & 0.21 & 0.16 & 0.40 \\
\hline LOQ (mg kg-1) & 2.00 & 1.7 & 0.73 & 2.53 & 0.71 & 0.53 & 1.35 \\
\hline
\end{tabular}

CV: Coefficient of variation; LOD: Limit of Detection; LOQ: Limit of Quantification 
Table 3. Tocopherols and tocotrienols (tocols) profile of analyzed cold-pressed seed oils (mg kg-1)

\begin{tabular}{|c|c|c|c|c|c|c|c|c|}
\hline \multicolumn{9}{|c|}{ Tocopherol and tocotrienol (tocol) composition data. mean \pm SD (mg kg-1) } \\
\hline $\begin{array}{l}\text { Cold } \\
\text { pressed } \\
\text { oils }\end{array}$ & $\alpha-T$ & $\beta-T$ & $\gamma-T$ & $\delta-T$ & $\alpha-T T$ & $\beta-T T$ & $\gamma-T T$ & $\begin{array}{l}\text { Total } \\
\text { Tocol }\end{array}$ \\
\hline $\begin{array}{l}\text { Pumpkin } \\
\text { seed }\end{array}$ & $9.83 \pm 2.29$ & $744.73 \pm 3.32$ & $88.90 \pm 1.90$ & nd & nd & nd & $\begin{array}{l}17.20 \\
\pm 1.21\end{array}$ & $860.64 \pm 1.71$ \\
\hline $\begin{array}{l}\text { Walnut } \\
\text { seed }\end{array}$ & $21.52 \pm 4.39$ & nd & $718.16 \pm 6.81$ & $39.46 \pm 3.85$ & $5.65 \pm 0.25$ & nd & $18.71 \pm 2.00$ & $803.50 \pm 2.05$ \\
\hline Flaxseed & $16.19 \pm 4.34$ & $222.88 \pm 1.38$ & $721.25 \pm 7.65$ & $17.14 \pm 0.72$ & nd & nd & nd & $977.47 \pm 5.07$ \\
\hline $\begin{array}{l}\text { Black } \\
\text { seed }\end{array}$ & $12.6 \pm 0.67$ & $28.45 \pm 2.05$ & $38.86 \pm 2.85$ & nd & $100.78 \pm 0.38$ & $295.84 \pm 1.47$ & $13.71 \pm 3.76$ & $490.24 \pm 1.02$ \\
\hline $\begin{array}{l}\text { Poppy } \\
\text { seed }\end{array}$ & $87.18 \pm 3.26$ & $9.18 \pm 1.00$ & $819.23 \pm 7.80$ & $16.23 \pm 3.23$ & nd & $\mathrm{nq}$ & nd & $931.82 \pm 7.50$ \\
\hline
\end{tabular}

Values are reported as means \pm SD of three replicate analyses $(n=3)$

T; Tocopherol. TT; Tocotrienol

nd; not detected

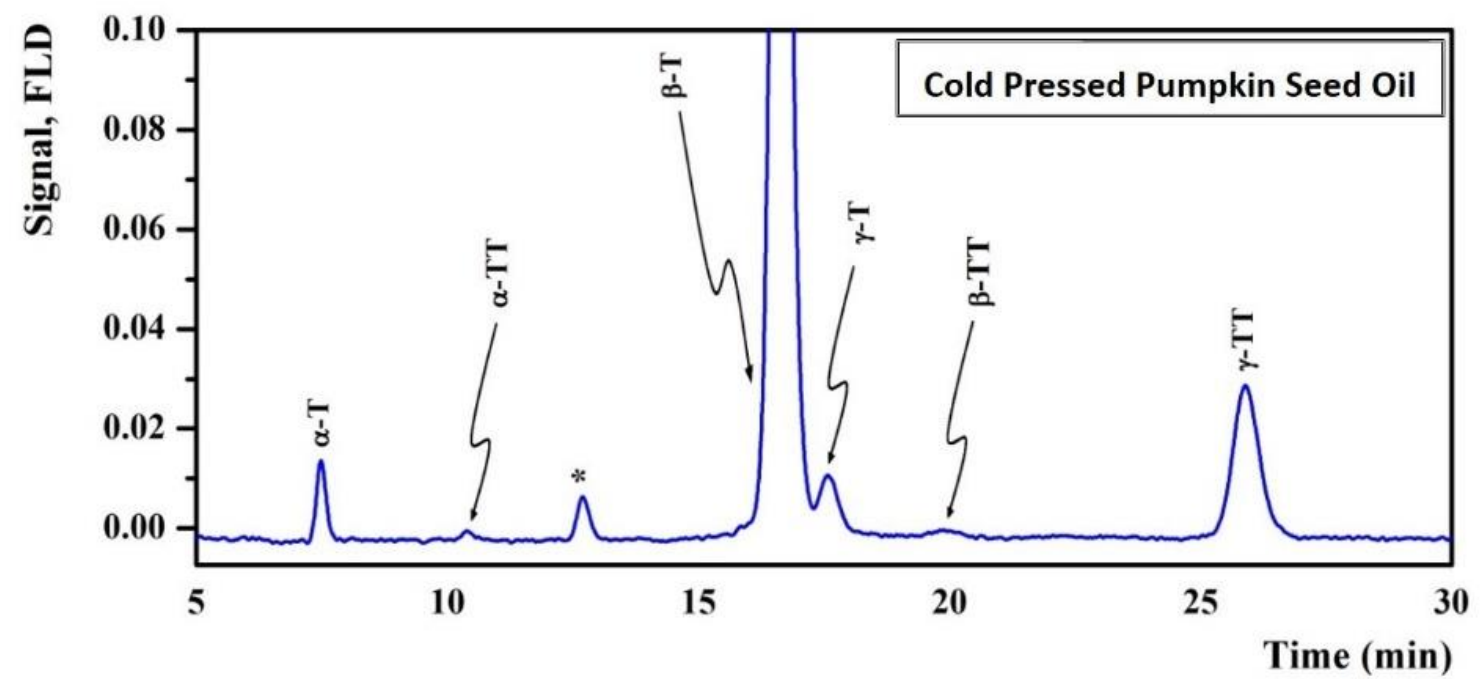

Figure 2. HPLC-FLD chromatogram of tocopherol/tocotrienol isomers for tested cold-pressed pumpkin seed oil

The $\alpha$-T content ranged between $9.83-87.18 \mathrm{mg} \mathrm{kg}^{-1}$ among all tested oils, as shown in Table 3. Coldpressed flaxseed and poppy seed oils exhibited a higher concentration of $\gamma$-T compounds (721.25 and $819.23 \mathrm{mg} \mathrm{kg}^{-1}$, respectively). On the other hand, the pumpkin seed contains the $\beta$ - $\mathrm{T}$ homolog at the predominant level $\left(744.73 \mathrm{mg} \mathrm{kg}^{-1}\right)$. The obtained values of tocols differ from the reported values (Bozan and Temelli, 2008; Neđeral et al., 2012). It may be due to the difference in the variety of oilseeds, environmental conditions, and origin

\subsection{OSI, FFA, PV, and IV Analyses}

In potential food applications, the oxidative stability of oils is an important quality parameter, expressed as the time required for oils to reach the critical oxidation point during processing and storage (Ayyildiz et al., 2015). Many literature studies show that primary and secondary oxidation products are 
taken into account in determining the stability of oils (Vidrih et al., 2010). For the estimation of the oxidative stability of cold pressed oils in this study, OSI, FFA, PV, and IV analyses were carried out and the outcomes are presented in Table 4.

Table 4. OSI, FFA, PV and IV of analyzed cold-pressed seed oils

\begin{tabular}{|c|c|c|c|c|}
\hline $\begin{array}{l}\text { Cold-pressed } \\
\text { oils }\end{array}$ & $\begin{array}{c}\text { OSI } \\
\text { at } 120^{\circ} \mathrm{C}(h)\end{array}$ & $\begin{array}{c}F F A \\
\text { (oleic acid, \%) }\end{array}$ & $\begin{array}{c}P V \\
\text { (meq } \mathrm{O}_{2} \mathrm{~kg}^{-1} \text { oil) }\end{array}$ & $\begin{array}{c}I V \\
\left(g I_{2} 100 g^{-1} \text { oil }\right)\end{array}$ \\
\hline Pumpkin seed & $4.31 \pm 0.23$ & $0.71 \pm 0.08$ & $1.83 \pm 0.09$ & $118.14 \pm 0.27$ \\
\hline Walnut seed & $3.98 \pm 0.42$ & $1.03 \pm 0.03$ & $2.81 \pm 0.14$ & $151.56 \pm 0.31$ \\
\hline Flaxseed & $4.15 \pm 0.37$ & $1.82 \pm 0.07$ & $2.76 \pm 0.21$ & $182.34 \pm 0.24$ \\
\hline Black seed & $3.57 \pm 0.28$ & $1.60 \pm 0.04$ & $2.59 \pm 0.17$ & $118.97 \pm 0.45$ \\
\hline Poppy seed & $4.92 \pm 0.39$ & $1.40 \pm 0.07$ & $2.43 \pm 0.08$ & $139.12 \pm 0.29$ \\
\hline
\end{tabular}

Data are described as means \pm SD of three replicate analyses $(n=3)$

OSI; oxidative stability index, FFA; free fatty acid, PV; peroxide value, IV; iodine value

The OSI is defined as a measure of the resistance of lipid molecules to oxidation, indicating the stability of the oil. The Rancimat method is the most important method in which the resistance of oils against oxidation can be determined easily and precisely by determining the total volatile secondary products that occur by accelerating the oxidation of oils (Pawar et al., 2014). During this oxidation process, the conductivity of water changes as the volatile compounds formed in the oil is absorbed in water, and a point called "induction time (IT)" or "induction period (IP)" is reached (Tarmizi et al., 2016). Table 4 shows the value of OSI ranged between 3.57- $4.92 \mathrm{~h}$ for all tested cold-pressed oils. Cold-pressed poppy seed oil has been found to have the highest oxidative stability among all seed oils tested, with an OSI of $4.92 \mathrm{~h}$ at $120^{\circ} \mathrm{C}$. OSI of the oil depends mainly on its FAC and tocols profile, and the rancimat results of the present study are almost comparable with already reported values with slight variations (Bozan and Temelli, 2008; Gharby et al., 2014).

FFA content, one of the important indicators of oil quality, occurs due to the hydrolysis of oils in the presence of heat and moisture (Satyarthi et al., 2011). When the chain length of the FA in oils is less than 14 carbons, the formation of an unpleasant taste and odor in the oil is observed (Mattes, 2009). To eliminate or reduce FFA impurities, the oil required to be refined, and the neutralization implementation reduces FFAs to a level of $0.05 \%$. The sodium hydroxide is used during the neutralization step in chemical refining, and the amount varies depending on the \% FFA content in oils (Gunstone, 2011). For cold-pressed oils, any physical or chemical implementation is not applied to remove FFAs, and also, in the present study, greater levels of FFA are observed (Table 4). For all tested oils, the maximum FFA value was found to be 1.82 for flaxseed oil. As shown in Table 4, the FFA content varies from 0.70 to $1.82 \%$ for all analyzed coldpressed seed oils.

The values obtained for PV, another quality parameter, are given in Table 4. PV is used to describe the hydroperoxides responsible for the off-taste in oil and is defined as primary oxidation products and the degree of oxidation of the oil in the early stages (Choe and Min, 2006). For all studied oils, the highest $\mathrm{PV}$ value was observed to be $2.76 \mathrm{meq} \mathrm{O}_{2} \mathrm{~kg}^{-1}$ oil and is in accordance with the Codex Alimentarius (Codex Alimentarius, 2001).

The PV ranged from 1.83 to $2.76 \mathrm{meq}_{2} \mathrm{~kg}^{-1}$ oil for all tested cold-pressed seed oils. The IV, categorized as a structure index, is related to the double bonds (number) present in the oil sample. IV index allows the correlation of chemical and physical properties with FAC. As shown in Table 4, the IV ranged between 151.56 - $182.34 \mathrm{~g} \mathrm{I}_{2} 100 \mathrm{~g}^{-1}$ oil for cold-pressed oils. The IV results obtained in the present study were found to be in good agreement with the FAC data available in the literature. 


\section{CONCLUSIONS}

In this study, the characteristics and stability of five cold-pressed seed oils were investigated.They were found to be of high quality due to their fatty acids, tocopherol distributions and oxidative stability indexes. It has been determined that all cold-pressed seed oils contain a high amount of PUFAs with known beneficial effects on health, and walnut oil has the highest PUFA content (72.02\%) among the oils studied. The seed oils are also rich in MUFAs and contain low content of total SFAs, and amongst the tested oils, pumpkin cold-pressed seed oil showed maximum SFAs content (17.70 \%). The oils also have high levels of tocopherol content, a source of natural antioxidants that are important for health and nutrition. The flaxseed oil, among the seed oils, was the richest in tocols content, $977.47 \mathrm{mg} \mathrm{kg}^{-1} \mathrm{oil}^{\mathrm{j}}$ containing $\alpha$-T $\left(16.19 \mathrm{mg} \mathrm{kg}^{-1}\right), \beta-\mathrm{T}\left(222.88 \mathrm{mg} \mathrm{kg}^{-1}\right), \gamma-\mathrm{T}\left(721.25 \mathrm{mg} \mathrm{kg}^{-1}\right)$ and $\delta-\mathrm{T}\left(17.14 \mathrm{mg} \mathrm{kg}^{-1}\right)$. It was also observed that the cold-pressed oils analyzed contained OSI, FFA, PV and IV under the limits allowed in the regulations. In conclusion, it is thought that the data obtained in this study will contribute to the studies on the standardization of cold-pressed seed oils approved for consumption and, the use of these oils in industries such as cosmetics, pharmaceuticals and food is expected to increase, due to their superior properties.

\section{ACKNOWLEDGEMENT}

The authors would like to thank Selcuk University for the facilities provided. They also like to thank TUBITAK for providing financial support to one of our research collaborator Professor Dr. S.T.H. Sherazi under TUBITAK 2221 Fellowship for Visiting Scientists and Scientists on Sabbatical Leave program.

\section{REFERENCES}

AOCS, 1996, "Method Cd 8b-90", Official methods and recommended practices of the American Oil Chemist's Society.

AOCS, 1998a, "Method Cd 1-25: Iodine value of fats and oils. Wijs Method", Official Methods and Recommended Practices of the American Oil Chemists' Society.

AOCS, 1998b, "AOCS official method Ca 5a-40: Free fatty acids. Official methods and recommended practices of the American Oil Chemists' Society".

AOCS, 1998c, "Method Cd 12b-92", Official Methods and Recommended Practices of the American Oil Chemists' Society.

Ayyildiz, H. F., Kara, H., \& Sherazi, S. T. H., 2011, "A novel approach for determination of free fatty acids in vegetable oils by a flow injection system with manual injection", Lipids, 46 (12), 1181-1190.

Ayyildiz, H. F., Topkafa, M., Kara, H., \& Sherazi, S. T. H., 2015, "Evaluation of fatty acid composition, tocols profile, and oxidative stability of some fully refined edible oils", International Journal of Food Properties, 18 (9), 2064-2076.

Bozan, B. and Temelli, F., 2008, "Chemical composition and oxidative stability of flax, safflower and poppy seed and seed oils", Bioresource Technology, 99 (14), 6354-6359.

Briggs, M. A., Petersen, K. S., \& Kris-Etherton, P. M., 2017, Saturated fatty acids and cardiovascular disease: replacements for saturated fat to reduce cardiovascular risk, Healthcare, 29.

Budilarto, E. S. and Kamal-Eldin, A., 2015, "The supramolecular chemistry of lipid oxidation and antioxidation in bulk oils", European Journal of Lipid Science and Technology, 117 (8), 1095-1137.

Cakaloglu, B., Ozyurt, V. H., \& Otles, S., 2018, "Cold press in oil extraction. A review", Ukrainian food journal (7, Issue 4), 640-654.

Celenk, V. U., Gumus, Z. P., Argon, Z. U., Buyukhelvacigil, M., \& Karasulu, E., 2018, "Analysis of chemical compositions of 15 different cold-pressed oils produced in Turkey: a case study of tocopherol and fatty acid analysis", Journal of the Turkish Chemical Society Section A: Chemistry, 5 (1), 1-18.

Choe, E. and Min, D. B., 2006, "Mechanisms and factors for edible oil oxidation", Comprehensive reviews in food science and food safety, 5 (4), 169-186. 
Čmolík, J. and Pokorný, J., 2000, "Physical refining of edible oils", European Journal of Lipid Science and Technology, 102 (7), 472-486.

Codex Alimentarius, F., 2001, "WHO: Fats, oils and related products", Codex Standard for Edible Fats and Oils Not Covered by Individual Standards.(CODEX STAN 210 1999).

Commission, E. U., 1991, "Regulation EEC 2568/91 on the characteristics of olive oil and olive pomace and their analytical methods", Off. J. Euro. Comm. L, 248, 1-83.

Delgado, A., Al-Hamimi, S., Ramadan, M. F., Wit, M. D., Durazzo, A., Nyam, K. L., \& Issaoui, M., 2020, "Contribution of Tocols to Food Sensorial Properties, Stability, and Overall Quality", Journal of Food Quality, 2020.

Febrianto, N. A. and Yang, T. A., 2011, "Producing high quality edible oil by using eco-friendly technology: a review", Advance Journal of Food Science and Technology, 3 (4), 317-326.

Ferguson, J. J., Stojanovski, E., MacDonald-Wicks, L., \& Garg, M. L., 2016, "Fat type in phytosterol products influence their cholesterol-lowering potential: A systematic review and meta-analysis of RCTs", Progress in lipid research, 64, 16-29.

Frančáková, H., Ivanišová, E., Dráb, Š., Krajčovič, T., Tokár, M., Mareček, J., \& Musilová, J, 2015, "Composition of fatty acids in selected vegetable oils", Potravinarstvo Slovak Journal of Food Sciences, 9 (1), 538-542.

Froyen, E. and Burns-Whitmore, B., 2020, "The Effects of Linoleic Acid Consumption on Lipid Risk Markers for Cardiovascular Disease in Healthy Individuals: A Review of Human Intervention Trials", Nutrients, 12 (8), 2329.

Gharby, S., Harhar, H., Boulbaroud, S., Bouzoubaa, Z., El-Madani, N., Chafchaouni, I., \& Charrouf, Z., 2014, "The stability of vegetable oils (sunflower, rapeseed and palm) sold on the Moroccan market at high temperature", International Journal of Chemical and Biochemical Sciences, 5, 47-54.

Grajzer, M., Szmalcel, K., Kuźmiński, Ł., Witkowski, M., Kulma, A., \& Prescha, A., 2020, "Characteristics and Antioxidant Potential of Cold-Pressed Oils-Possible Strategies to Improve Oil Stability", Foods, 9 (11), 1630.

Griffin, B. A., 2008, "How relevant is the ratio of dietary n-6 to n-3 polyunsaturated fatty acids to cardiovascular disease risk? Evidence from the OPTILIP study", Current opinion in lipidology, 19 (1), 57-62.

Gunstone, F., 2011, Vegetable oils in food technology: composition, properties and uses, John Wiley \& Sons, p.

Husted, K. S. and Bouzinova, E. V., 2016, "The importance of n-6/n-3 fatty acids ratio in the major depressive disorder", Medicina, 52 (3), 139-147.

Khattab, R. Y. and Zeitoun, M. A., 2013, "Quality evaluation of flaxseed oil obtained by different extraction techniques", LWT-Food Science and Technology, 53 (1), 338-345.

Kramer, J. K., Blais, L., Fouchard, R. C., Melnyk, R. A., \& Kallury, K. M., 1997, "A rapid method for the determination of vitamin $\mathrm{E}$ forms in tissues and diet by high-performance liquid chromatography using a normal-phase diol column", Lipids, 32 (3), 323-330.

Kris-Etherton, P. M., Taylor, D. S., Yu-Poth, S., Huth, P., Moriarty, K., Fishell, V., ... \& Etherton, T. D., 2000, "Polyunsaturated fatty acids in the food chain in the United States", The American journal of clinical nutrition, 71 (1), 179S-188S.

Kyriakidis, N. B. and Katsiloulis, T., 2000, "Calculation of iodine value from measurements of fatty acid methyl esters of some oils: comparison with the relevant American oil chemists society method", Journal of the American Oil Chemists' Society, 77 (12), 1235-1238.

Lacoste, F., 2014, "Undesirable substances in vegetable oils: anything to declare?", Ocl, 21 (1), A103.

Mattes, R. D., 2009, "Is there a fatty acid taste?", Annual review of nutrition, 29, 305-327.

Medina-Juárez, L. Á. and Gámez-Meza, N., 2011, "Effect of refining process and use of natural antioxidants on soybean oil", Soybean-Biochemistry, Chemistry and Physiology. InTech, 435-460.

Naz, S., Sherazi, S. T. H., \& Talpur, F. N., 2011, "Changes of total tocopherol and tocopherol species during sunflower oil processing", Journal of the American Oil Chemists' Society, 88 (1), 127-132. 
Neđeral, S., Škevin, D., Kraljić, K., Obranović, M., Papeša, S., \& Bataljaku, A., 2012, "Chemical composition and oxidative stability of roasted and cold pressed pumpkin seed oils", Journal of the American Oil Chemists' Society, 89 (9), 1763-1770.

Orsavova, J., Misurcova, L., Ambrozova, J. V., Vicha, R., \& Mlcek, J., 2015, "Fatty acids composition of vegetable oils and its contribution to dietary energy intake and dependence of cardiovascular mortality on dietary intake of fatty acids", International journal of molecular sciences, 16 (6), 1287112890.

Özbek, Z. A., Çelik, K., \& Ergönül, P. G., 2020, "Consumers Knowledge About Health Effects of Edible Oils and Fats in Turkey: A Questionnaire Study", Age (years), 18 (30), 102.

Pachuau, L., Devi, C. M., Goswami, A., Sahu, S., \& Dutta, R. S., 2019, Seed Oils as a Source of Natural Bioactive Compounds, In: Natural Bio-active Compounds, Eds: Springer, p. 209-235.

Pal, U., Patra, R. K., Sahoo, N. R., Bakhara, C. K., \& Panda, M. K., 2015, "Effect of refining on quality and composition of sunflower oil", Journal of food science and technology, 52 (7), 4613-4618.

Pawar, N., Purohit, A., Gandhi, K., Arora, S., \& Singh, R. R. B., 2014, "Effect of operational parameters on determination of oxidative stability measured by Rancimat method", International Journal of Food Properties, 17 (9), 2082-2088.

Prescha, A., Grajzer, M., Dedyk, M., \& Grajeta, H., 2014, "The antioxidant activity and oxidative stability of cold-pressed oils", Journal of the American Oil Chemists' Society, 91 (8), 1291-1301.

Ramadan, M. F., 2020, Introduction to cold pressed oils: Green technology, bioactive compounds, functionality, and applications, In: Cold Pressed Oils, Eds: Elsevier, p. 1-5.

Satyarthi, J., Srinivas, D., \& Ratnasamy, P., 2011, "Hydrolysis of vegetable oils and fats to fatty acids over solid acid catalysts", Applied Catalysis A: General, 391 (1-2), 427-435.

Szydłowska-Czerniak, A., Karlovits, G., Dianoczki, C., Recseg, K., \& Szłyk, E., 2008, "Comparison of two analytical methods for assessing antioxidant capacity of rapeseed and olive oils", Journal of the American Oil Chemists' Society, 85 (2), 141-149.

Tarmizi, A. H. A., Ahmad, K., Sahri, M. M., \& May, C. Y., 2016, "Rancimat test for measuring the oxidative stability of cooking oils upon prolonged frying", Journal of Oil Palm Research, 28 (4), 531-535.

Traber, M. G. and Atkinson, J., 2007, "Vitamin E, antioxidant and nothing more", Free radical biology and medicine, 43 (1), 4-15.

Uluata, S. and Özdemir, N., 2012, "Antioxidant activities and oxidative stabilities of some unconventional oilseeds", Journal of the American Oil Chemists' Society, 89 (4), 551-559.

Vidrih, R., Vidakovič, S., \& Abramovič, H., 2010, "Biochemical parameters and oxidative resistance to thermal treatment of refined and unrefined vegetable edible oils", Czech Journal of Food Sciences, 28 (5), 376-384.

Vujasinovic, V., Djilas, S., Dimic, E., Romanic, R., \& Takaci, A., 2010, "Shelf life of cold-pressed pumpkin (Cucurbita pepo L.) seed oil obtained with a screw press", Journal of the American Oil Chemists' Society, 87 (12), 1497-1505.

Vujasinovic, V., Djilas, S., Dimic, E., Basic, Z., \& Radocaj, O., 2012, "The effect of roasting on the chemical composition and oxidative stability of pumpkin oil", European Journal of Lipid Science and Technology, 114 (5), 568-574.

Wardana, I., Widodo, A., \& Wijayanti, W., 2018, "Improving vegetable oil properties by transforming fatty acid chain length in jatropha oil and coconut oil blends", Energies, 11 (2), 394.

Wijendran, V. and Hayes, K., 2004, "Dietary n-6 and n-3 fatty acid balance and cardiovascular health", Annu. Rev. Nutr., 24, 597-615.

Yamauchi, R., 1997, "Vitamin E: mechanism of its antioxidant activity", Food Science and Technology International, Tokyo, 3 (4), 301-309.

Yaqoob, P., 1998, "Monounsaturated fats and immune function", Proceedings of the Nutrition Society, 57 (4), 511-520.

Yehuda, S., Rabinovitz, S., \& Mostofsky, D. I., 2001, PUFA: mediators for the nervous, endocrine, and immune systems, In: Fatty Acids, Eds: Springer, p. 403-420. 
Ying, Q., Wojciechowska, P., Siger, A., Kaczmarek, A., \& Rudzińska, M., 2018, "Phytochemical content, oxidative stability, and nutritional properties of unconventional cold-pressed edible oils", Journal of Food and Nutrition Research, 6 (7), 476-485.

Yusuf, A., 2018, "A review of methods used for seed oil extraction", Int. J. Sci. Res, 7 (12), 233-223.

Žilić, S., Dragišić, J. M., Maksimović, V., Maksimović, M., Basić, Z., Crevar, M., \& Stanković, G., 2010, "The content of antioxidants in sunflower seed and kernel", Helia, 33 (52), 75-84. 